\title{
Российские производители гражданской электроники станут основными игроками рынка
}

\author{
Пресс-конференция, посвященная презентации проекта
} Стратегии развития электронной промышленности России на период до 2030 года

\section{С. Попов}

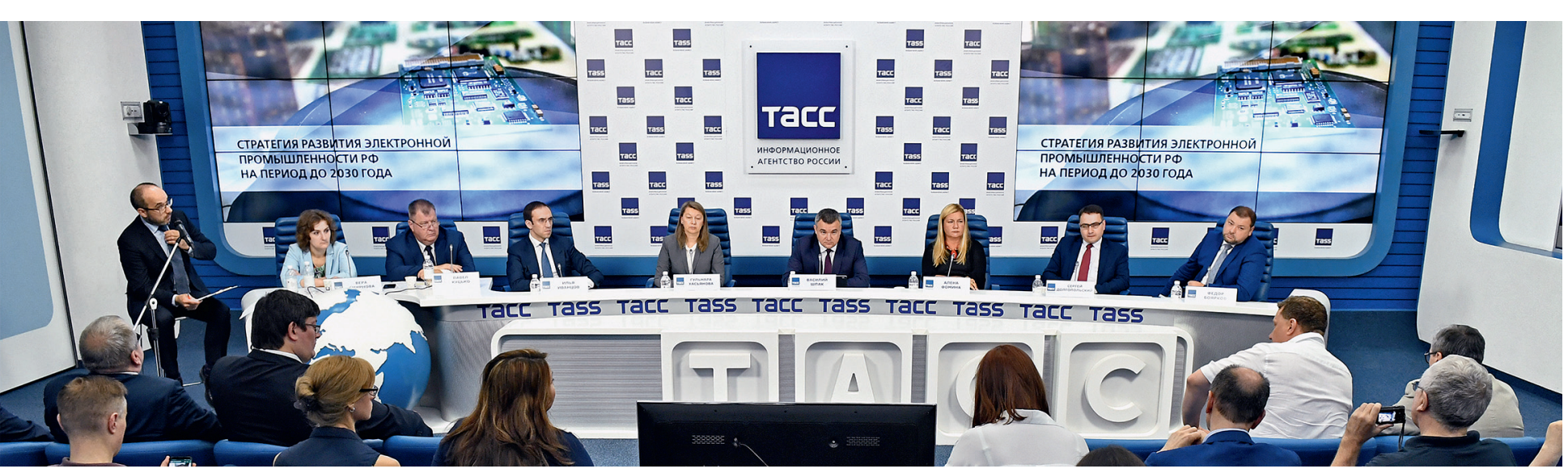

Согласно разработанной Минпромторгом России Стратегии развития электронной промышленности Российской Федерации на период до 2030 года объемы производства в отрасли должны вырасти более чем в 2,5 раза. Планируется серьезно увеличить и показатели экспорта. За тот же период гражданский сектор электроники должен вырасти примерно в пять раз - с 940 млрд до 4,6 трлн руб.

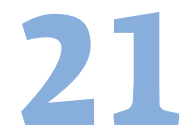

августа в ТАСС состоялась пресс-конференция посвященная презентации проекта Стратегии развития электронной промышленности России на период до 2030 года. В ней приняли участие представители Минпромторга России и ряда ведущих отечественных компаний и отраслевых объединений

Директор Департамента радиоэлектронной промышленности Минпромторга России В.В.Шпак отметил, что представленный документ ориентирован на ускоренное развитие отрасли в целом - от производства электронной компонентной базы (ЭКБ) до выпуска продукции для конечных потребителей, например средств связи. Приоритетными направлениями станут кадры, научно-техническое развитие, средства производства, управление, кооперация, отраслевые стандарты, отраслевая информационная среда, капитализация, рынки и продукты, финансовое обеспечение и инвестиционная привлекательность.
Успешная реализация основных мероприятий предыдущей версии документа с горизонтом планирования до 2025 года (утвержден Приказом Министерства промышленности и энергетики Российской Федерации от 7 августа 2007 года № 311) позволила за последнее десятилетие восстановить кооперационные связи в отрасли, выстроить производственные цепочки, необходимые для выполнения государственного оборонного заказа и создания новых образцов вооружений.

Основная идея новой стратегии - регулирование. Какподчеркнул В. В. Шпак, "главный барьер сегодня - в головах. Нам вполне по силам пройти путь от места, где находится наша электронная промышленность сейчас, до того, где она должна быть, - в числелидеров. Надо перестать бояться защищать собственный рынок. Мы должны декларировать, что государство готово создавать благоприятные условия для отечественных производителей с целью их развития с последующим доминированием на своем рынке. Все ведущие страны мира ведут такую политикудостаточно давно и успешно». Что касается 
зарубежных компаний, то во всех развитых странах они не могут выйти на рынок без локализации производства. Россия не должна быть исключением.

Государство обеспечит защиту внутреннего рынка, а также развитие отрасли через такие инструменты, как прямой госзаказ, субсидии, налоговые льготы, прямую финансовую поддержку в проведении НИОКР в критически важных областях. Одним из первых кирпичей в фундамент строящегося здания стало Постановление Правительства Российской Федерации от 10 июля 2019 года № 878, касающееся мер стимулирования производства радиоэлектронной продукции на территории Российской Федерации при осуществлении закупок товаров, работ, услуг для обеспечения государственных и муниципальных нужд. Перечень продукции, происходящей из иностранных государств, в отношении которой данным документом вводятся ограничения, будет корректироваться примерно раз в полгода.

Успешно работает программа субсидирования НИОКР в рамках Постановления Правительства Российской Федерации от 17 февраля 2016 года № 109. Как рассказал В. В. Шпак, с начала 2020 года планируется ввести в нее новую, пятую, подпрограмму субсидирования, касающуюся микроэлектроники. Более того, Минпромторг России будет добиваться изменения соотношения собственных и государственных денег с 50:50, которое действует сегодня, на 30:70.

Цели новой отраслевой стратегии будут достигаться в три этапа, на каждом из которых делается акцент на освоение определенных перспективных рынков гражданской продукции. Как подчеркнул В. В. Шпак, только на рынке гражданской электроники можно добиться тех объемов выпуска продукции, которые позволят зарабатывать средства, необходимые компаниям-производителям для финансирования НИОКР

На первом этапе, в нынешнем и 2020 году, основное внимание будет уделено традиционным рынкам, таким как телекоммуникационное и навигационное оборудование, вычислительная техника (включая системы хранения данных), автоэлектроника, системы автоматизации.

На втором этапе - с 2021 по 2024 год - планируется охватить новые рынки, среди которых - интеллектуальная энергетика, телемедицина, беспилотная авиация, Интернет вещей и мобильная связь пятого поколения (5С).

С 2025 года необходимо будет сфокусироваться на прорывных направлениях, связанных с робототехникой, искусственным интеллектом, всеми видами беспилотного транспорта, нейротехнологиями и квантовыми вычислениями.

\section{БУДУЩЕЕ - ЗА КОНСОРЦИУМАМИ}

Отечественная электронная отрасль должна развиваться на основе производственных консорциумов. Эта мысль красной нитью прошла через выступления большинства участников данной пресс-конференции. Какпояснил В. В. Шпак, под таким консорциумом можно понимать любое отраслевое объединение, которое добивается совместных целей. С точки зрения
Минпромторга России, для того чтобы называться консорциумом, нужно иметь понятную линейку оборудования с дорожной картой ее создания на перспективу не менее 7-10 лет.

«Консорциум должен заниматься не только верхним уровнем создания прибора, но и участвовать во всей технологической цепочке- проектировании, разработке ПО, производстве, сервисной поддержке, гарантийном и постгарантийном обслуживании. Он должен сопровождать всю продуктовую линейку от момента создания до утилизации. В составе консорциумов желательно участие вузов и сертификационных центров", - сказал представитель Минпромторга России.

Консорциумы могут быть созданы в таких сферах, как телекоммуникации, вычислительная техника, электроника для сельского хозяйства, автоэлектроника (включая телематические приборы), авиационное приборостроение, железнодорожное приборостроение, искусственный интеллект, квантовые вычисления и др.

Г.Ш.Хасьянова, генеральный директор ПАО «Микрон", одного из ведущих производителей микроэлектроники, отметила: "Мы считаем, что крайне важно создать экосистему вокруг производства - дизайн-центры, производители материалов и оборудования, ориентированные на наши конкретные фабрики. Для этого необходимы меры стимулирования дизайн-центров производить чипы в России и меры по обеспечению спроса на эти чипы. Это запустит цепную реакцию по развитию производителей материалов и комплектующих и других участников рынка по всей цепочке добавленной стоимости».

Генеральный директор "Микрона» подчеркнула, что для консолидации рынка необходимо разработать стандарты, что позволит консолидировать заказ на ЭКБ, обеспечить унификацию, серийность и конкурентоспособную цену российской продукции.

Директор ФГуп "МнИИРИП" П.П. Куцько поддержал тезис, что в основе качества продукции лежит стандартизация. До сих пор драйвером развития отрасли были оборонные заказы. Соответственно, на них ориентировалась и российская стандартизация. Разработка стандартов на продукцию гражданского назначения позволит сделать последнюю более доступной для широких кругов заказчиков и успешно конкурировать с импортом. При необходимости использования того или иного продукта в космической, оборонной или иной отрасли с повышенными требованиями стандарт будет соответственно дорабатываться.

Тему консорциумов развил президент ОоО "Элемент" И.Г.Иванцов, отметивший, что на вновь разработанную стратегию стоит смотреть, как на план объединения усилий российских компаний. За последние три-четыре года объем консолидационных сделок на мировом рынке микроэлектроники составил более 150 млрд долл. Разработка одного процессора может потребовать от единиц до десятков миллионов долларов. Для отрасли критически важен масштаб, нужны отраслевые чемпионы. 